\title{
PHENOTYPIC CHANGES OF FAT IN LORI-BAKHTIARI FAT-TAILED SHEEP
}

\author{
Mohammad Ali Talebi \\ Department of Animal Science, Agriculture and Natural Resources Research Center, Sharekord, Iran \\ maitalebi@yahoo.com
}

\begin{abstract}
The data set used in this study was body weight at 6 months of age (BW6M), fat-tailed weight (EFTW) and hypodermic needle measure of soft tissue at $12-13^{\text {th }}$ rib, $120 \mathrm{~mm}$ from the midline (GR) of 2391 lambs at 6 months of age recorded over a 8-year period (2003 to 2011) from a Lori-Bakhtiari research flock in the Chaharmahal and Bakhtiari province, Iran. The flock is managed under a semi-migratory or village system. SAS procedures were used for the statistical analysis. Average of BW6M, EFTW and needle soft tissue depth measured in live lambs (NGR) estimated at the age of six months in lambs were $43.30,2.73 \mathrm{~kg}$ and $7.36 \mathrm{~mm}$, respectively. During the selection program for reducing fat, 4.45 percent of the fat-tailed decreased. Fat-tailed weight per kg of the body weight decreased from $78 \mathrm{~g}$ to $52 \mathrm{~g}$ in the end of the program. The effects of sex, year of birth, type of birth and rearing type were significant for the BW6M and EFTW traits. The phenotypic trends for EFTW and NGR regressed in the year of birth with constant weight were $-140 \mathrm{~g} /$ year and $-0.37 \mathrm{~mm} /$ year, respectively. The phenotypic trend for the BW6M was positive $(0.744 \mathrm{~kg} /$ year$)$. Consequently, the phenotypic progress is possible for decreasing fat without decreasing body weight, too.
\end{abstract}

Key words: fat; phenotypic trend; Lori-Bakhtiari; sheep

\section{ФЕНОТИПСКИ ПРОМЕНИ НА МАСТИ ВО ОПАШКА НА ОВЦИ ОД РАСАТА ЛОРИ-БАКХТИАРИ}

\begin{abstract}
Податоци кои се користени во оваа студија беа телесната тежина во период од 6 месеци (BW6M), тежина на мастите во опашката (EFTW) и дебелина на поткожното меко ткиво измерено со помош на игла помеѓу 12 и 13-то ребро, $120 \mathrm{~mm}$ од средната линија (GR) на 2391 јагне на возраст од 6 месеци следени во текот на 8-годишен период (2003-2011) кај овци од расата Lori-Bakhtiari во покраините Chaharmahal и Bakhtiari во Иран. Стадото е одгледувано под полуномадски или селски систем. За статистички анализи беа користени процедури SAS. Просекот од BW6M, EFTW и дебелината на поткожното масно ткиво кај живи јагниња (NGR) на возраст од шест месеци изнесуваше 43,30, $2,73 \mathrm{~kg}$ и 7,36 mm, соодветно. За време на изборот на програма за намалување на мастите во опашката беа намалени $4,45 \%$. Масата на мастите во опашка на килограм телесна тежина се намали од $78 \mathrm{~g}$ до $52 \mathrm{~g}$ на крајот од програмата. Ефектите на полот, годината на раѓање, типот на раѓање и типот на одгледување беа значајни за својствата на BW6M и EFTW. Фенотипските трендови за EFTW и NGR назадуваше во годината на раѓање со константна тежина од $-140 \mathrm{~g} /$ годишно и $-0,37 \mathrm{~mm} /$ годишно, соодветно. Фенотипскиот тренд за BW6M беше позитивен $(0,744 \mathrm{~kg} /$ годишно). Како резултат на тоа, фенотипски е можно намалување на мастите без намалување на телесната тежина.
\end{abstract}

Клучни зборови: масти, фенотипски тренд, Lori-Bakhtiari, овци.

\section{INTRODUCTION}

Programming for reducing fat content in herbivore animals is a long-term animal production objective in most countries. In Iran, the major income from the sheep industry is meat production and an economically sustainable production is conditional on the farmer's ability to produce high quality carcasses. However, carcass characteristics such as carcass fatness are obtained after the animal is slaughtered. By receiving the information at such a late stage, it is not possible to select animals for breeding based on their own record, but only the records on relatives. Therefore, information on indicators of carcass quality, which can be measured when the animal is still alive, will contribute with important information in a breeding program where carcass quality is included. 
More than $96 \%$ of Iranian sheep are fat-tailed (Kiyanzad, 2005). In lambs, carcass adiposity and particularly the fat-tail reduce the fat-tailed lamb meat value. Lean lamb can be produced from manipulation of the nutritional regimen or a selection program. For both paths, the knowledge of lamb carcass composition and its evolution is required. The major problem is the absence of any practical way for recording or predicting phenotypic fat-tail weight of live sheep in Lori-Bakhtiari or other breeds. Fat-tail weight cannot be measured in live animals, and the volume determined by water displacement is neither reliable nor feasible for large fat-tails. However, fat-tail dimensions can be easily measured on live animals and could be used as an indicator of fat-tail weight in breeding programs.

Tissue boundaries can be mapped and used to predict body composition (Simm, 1992). Fatness classes are specified by the GR measurement. GR is correlated highly with other common fatness measurements and is as closely related to carcass composition as can be expected of any single, onedimensional fat measurement (Kirton, 1989). GR is a measurement included in carcass grading systems to predict lean and fat yield in Canada (Jones et al., 1996), Australia (Hopkins, 1994), and New Zealand (Kirton and Johnson, 1979; Kenney et al., 1995). Hypodermic needle measures on live animals are a relatively low cost method, which can give information on carcass traits for further inclusion in genetic evaluation programmes.

Solisramirez et al. (1993) have found that selection for changed body composition resulted in correlated anatomical changes. Selection programmes including live weight- or age adjusted needle and ultrasound measurements have shown to give high responses in lean growth (Ramsey et al, 1991; Simm et al., 2002; Larsgard and Kolstad, 2003; Kvame and Vangen, 2007).

Nsoso et al. (2004) have shown that live weight and muscle depth increased and fat depth decreased under selection for lean tissue growth. The aim of the current study was to determaine the phenotypic changes for fat weight and body weight of Lori-Bakhtiari sheep.

\section{MATERIAL AND METODS}

The data set used in this study was the body weight at 6 months of age (BW6M), fat-tailed weight (EFTW), fat-tailed weight per $\mathrm{kg}$ of the body weight (DGEFTW), percentage of fat-tailed weight to carcass weight (PEFTW) and hypoder- mic needle measurement of soft tissue over the $12^{\text {th }}$ rib, $120 \mathrm{~mm}$ from the dorsal midline (GR) of 2391 lambs at 6 months of age recorded from a LoriBakhtiari research flock in Shahrekord. The data had been collected during eight years, from 2003 to 2011 . The selection program was undertaken at the breeding station of the Lori-Bakhtiari sheep in Chaharmahal and Bakhtiari province, Iran. The flock is managed under a semi-migratory or village system. The flock is kept generally from December to May at the station and in this period is fed with alfalfa, barely and wheat stubble indoors. The sheep graze on the range and cereal pastures the rest of the year. The breeding period extends from late August to late October (ewes are assigned randomly to the selected rams) and consequently, lambing starts in late January. During pre weaning time, lambs suckle their mothers and from 15 days of age they have access to creep feed ad-libitum and they are weaned at an average age of $90 \pm 5$ days. After weaning male and female lambs are separated. Female lambs are kept on the pasture of cultivated alfalfa, while males are kept indoors and fed using maintenance and growth ration to 6 months of age. Body weight and external fat-tailed dimensions were recorded at 6 month of age. Various external fat-tail dimensions were included: lower width, length (from the point of attachment to the tip) and middle circumference (at the point of middle of fat-tail). All fat-tail measurements were done with a measuring tape to the nearest 0.5 $\mathrm{cm}$. All measurements were made while the animal was holden in a standing position. Of these about 311 lambs were slaughtered at the age of six months. After slaughtering and skinning, all the abdominal and thoracic organs were removed. The fatty tissues surrounding kidney (kidney fat), heart (pericardial fat) and those in the abdominal cavity (omental and mesentery fat) were separated and weighted. The warm carcass was weighed immediately after dressing and removal of offal parts. The carcasses were chilled at $3 \pm 2{ }^{\circ} \mathrm{C}$ for approximately $18 \mathrm{~h}$, and then cold carcasses were weighed. Then fat-tailed was removed and weighted. Prediction equations were derived for fat-tailed weight by multiple regression analyses (Talebi and Vatankhah, 2011). A needle measurement of soft tissue depth at GR site (NGR) was made with a 22gauge hypodermic needle in live lambs at 6 months of age. Before hypodermic needle measurements, the wool was clipped close to the skin and shaved at measurement site. Hypodermic needle was inserted until the lateral surface of the $12^{\text {th }}$ rib. 
Data were analyzed by the GLM procedure of SAS (2002). The statistical model for the analyses of all the carcass characteristics traits included fixed effects due to the year of birth, type of birth of lamb (single and twin), age of dam (six classes), kind of rearing after weaning (two classes included group feeding and individual feeding) and weight of lamb at evaluation or slaughter as covariate for traits of EFTW, NGR and percentage of fat-tailed weight to carcass weight (PEFTW). Phenotypic trends were computed by regressing estimated phenotypic values of traits on the year of birth using the procedure of REG of the Statistical Analysis System (SAS, 2002).

\section{RESULTS AND DISCUSSION}

The average, standard deviation and coefficients of variation traits are shown in Table 1. Mean of BW6M, EFTW, PEFTW and ratio of fattail to the body weight (REFTW) at the age of six months were $43.30,2.73 \mathrm{~kg}, 11.86 \%$ and $59 \mathrm{gr}$, respectively. The reports indicated that the weight of fat-tail in fattened lambs of different Iranian breeds and sexes ranged between 6.39 to $25.26 \%$ of carcass (Farid et al., 1983).

The average NGR at the age of six months was $7.36 \mathrm{~mm}$. This agrees with values reported for the GR tissue depth which have ranged from 7.1 to
10.1 in strains of Australian Merino sheep (Fogarty et al., 2003). Soft tissue depth with needle at $12^{\text {th }}$ rib in Moghani and Makui Iranian fat-tailed breeds were $5.40 \pm 1.50$ and $4.14 \pm 1.26 \mathrm{~mm}$, respectively (Kiyanzad, 2004). These differences were due to lower body weight (38.64 and 36.30, respectively) and variation in NGR of Moghani and Makui breeds than Lori-Bakhtiari lambs. NGR in New Zealand mixed breed was $7.8 \mathrm{~mm}$ (Ramsey et al., 1991), which is not very different from LoriBakhtiari lambs.

The coefficient of variation for $6 \mathrm{MW}$ was 22.37 percent which was in the range reported by Fogarty (1995) and Safari et al. (2005). Coefficients of variation for EFTW, REFTW and NGR traits were $52.9,38.2$ and 31.1 , respectively and relatively high. Waldron et al. (1992) reported that the coefficient of variation for fat was 25 percent in the carcass of lambs of Romney and its crosses. The coefficient of variation for the GR tissue depth was $47 \%$ in the strains of the Merino sheep (Fogarty et al., 2003). Cadavez (2009) also observed that subcutaneous fat thickness measurements (in three points of rib and lumbar vertebrae) had the highest coefficient of variation $(>44.5 \%)$ of all the measurements recorded. It is important to note, that considerable variation exists for the growth and especially for the carcass fat.

Table 1

The average, standard deviation, coefficients of variation traits.

\begin{tabular}{llrrr}
\hline \hline Trait acronyms & Trait & Mean & SD & CV \\
\hline BW6M & Body weight at 6 months of age & 43.30 & 9.69 & 22.3 \\
EFTW & Fat-tail weight & 2.73 & 1.45 & 52.9 \\
NGR & Needle measurement at GR site & 7.36 & 2.29 & 31.1 \\
PEFTW & Percentage of fat-tail & 11.86 & 4.53 & 12.3 \\
DGEFTW & Fat-tailed weight per kg of body weight & 59 & 22 & 38.2 \\
\hline \hline
\end{tabular}

Least squares means of the effect of the year of birth, sex, type of birth, age of dam, type of rearing and operator on BW6M, EFTW, NGR, PEFTW and DGEFTW traits are presented in Table 2. Year of birth and sex were significantly different $(\mathrm{P}<0.001)$ for all traits studied. The body weight at the six months of age did not fall at the end of phenotypic selection programs. Fat-tailed weight, percentage of fat-tailed weight and soft tissue depth traits decreased significantly at the end of program. Fat-tailed weight percentage of fattailed weight and soft tissue depth traits were decreased with the increase of live weight of LoriBakhtiari lambs. Therefore, body fat (fat-tailed and subcutaneous fat) decreased with phenotypic selection. Larsgard and Kolstad (2003) showed a significant and increasing difference in ultrasonic muscle depth $(2.1 \mathrm{~mm})$ between the lines throughout the entire period. 
Tab 1 e 2

Least-square means and standard error (S.E.) of traits ${ }^{\dagger}$ for different levels of fixed effects in Lori-Bakhtiari lambs

\begin{tabular}{|c|c|c|c|c|c|c|}
\hline \multirow[t]{2}{*}{ Effect } & \multirow{2}{*}{$\begin{array}{l}\text { No. of } \\
\text { records }\end{array}$} & \multicolumn{5}{|c|}{ Traits } \\
\hline & & BW6M & EFTW & NGR & PEFTW & DGEFTW \\
\hline Year & 2391 & $* * *$ & $* * *$ & $* * *$ & $* * *$ & $* * *$ \\
\hline 1 & 335 & $44.85 \pm 0.60^{\mathrm{ab}}$ & $3.39 \pm 0.06^{\mathrm{a}}$ & $8.48 \pm 0.12^{b}$ & $14.59 \pm 0.30^{\mathrm{a}}$ & $78 \pm 2^{\mathrm{a}}$ \\
\hline 2 & 325 & $44.16 \pm 0.59^{\mathrm{abc}}$ & $2.94 \pm 0.06^{\mathrm{c}}$ & $7.89 \pm 0.12^{\mathrm{c}}$ & $12.42 \pm 0.30^{\mathrm{c}}$ & $65 \pm 2^{c}$ \\
\hline 3 & 159 & $44.83 \pm 0.66^{\mathrm{ab}}$ & $3.14 \pm 0.07^{\mathrm{b}}$ & $7.65 \pm 0.15^{\mathrm{c}}$ & $13.17 \pm 0.34^{\mathrm{b}}$ & $73 \pm 2^{b}$ \\
\hline 4 & 336 & $43.57 \pm 0.56^{\mathrm{ce}}$ & $2.94 \pm 0.06^{\mathrm{c}}$ & $8.85 \pm 0.10^{\mathrm{a}}$ & $12.39 \pm 0.28^{\mathrm{c}}$ & $64 \pm 2^{c}$ \\
\hline 5 & 327 & $42.55 \pm 0.54^{\mathrm{d}}$ & $2.87 \pm 0.05^{\mathrm{c}}$ & $8.36 \pm 0.10^{b}$ & $12.14 \pm 0.28^{\mathrm{cd}}$ & $60 \pm 2^{\mathrm{d}}$ \\
\hline 6 & 300 & $43.95 \pm 0.45^{\mathrm{bcd}}$ & $2.62 \pm 0.05^{\mathrm{d}}$ & $7.25 \pm 0.10^{\mathrm{d}}$ & $11.29 \pm 0.23^{\mathrm{d}}$ & $56 \pm 1^{d}$ \\
\hline 7 & 294 & $43.87 \pm 0.56^{\mathrm{bcd}}$ & $2.37 \pm 0.06^{\mathrm{e}}$ & $5.24 \pm 0.11^{\mathrm{e}}$ & $10.35 \pm 0.28^{\mathrm{e}}$ & $51 \pm 2^{\mathrm{e}}$ \\
\hline 8 & 315 & $45.49 \pm 0.55^{\text {ae }}$ & $2.34 \pm 0.04^{\mathrm{e}}$ & $6.13 \pm 0.10^{\mathrm{f}}$ & $10.14 \pm 0.28^{\mathrm{e}}$ & $52 \pm 2^{\mathrm{e}}$ \\
\hline Sex of lambs & & $* * *$ & $* * *$ & $* * *$ & $* * *$ & $* * *$ \\
\hline female & 1155 & $39.34 \pm 0.30^{\mathrm{a}}$ & $2.73 \pm 0.03^{\mathrm{a}}$ & $7.97 \pm 0.09^{\mathrm{a}}$ & $11.49 \pm 0.16^{\mathrm{a}}$ & $52 \pm 1^{\mathrm{a}}$ \\
\hline male & 1236 & $48.97 \pm 0.21^{\mathrm{b}}$ & $2.93 \pm 0.02^{b}$ & $6.99 \pm 0.06^{\mathrm{b}}$ & $12.79 \pm 0.13^{\mathrm{b}}$ & $73 \pm 1^{\mathrm{b}}$ \\
\hline Type of birth & & $* * *$ & $*$ & Ns & $*$ & $* * *$ \\
\hline Single & 1723 & $46.13 \pm 0.21^{\mathrm{a}}$ & $2.86 \pm 0.02^{\mathrm{a}}$ & $7.44 \pm 0.06^{\mathrm{a}}$ & $12.30 \pm 0.12^{\mathrm{a}}$ & $66 \pm 1^{\mathrm{a}}$ \\
\hline Twin & 668 & $42.18 \pm 0.27^{\mathrm{b}}$ & $2.80 \pm 0.03^{b}$ & $7.53 \pm 0.08^{\mathrm{a}}$ & $11.97 \pm 0.14^{\mathrm{b}}$ & $59 \pm 1^{b}$ \\
\hline Age of dam & & $* * *$ & $* * *$ & Ns & $*$ & $* *$ \\
\hline 2 & 545 & $42.64 \pm 0.29^{c}$ & $2.77 \pm 0.03^{\mathrm{cd}}$ & $7.57 \pm 0.08^{\mathrm{a}}$ & $11.96 \pm 0.15^{\mathrm{b}}$ & $59 \pm 1^{d}$ \\
\hline 3 & 531 & $44.35 \pm 0.29^{\mathrm{ab}}$ & $2.76 \pm 0.03^{\mathrm{d}}$ & $7.46 \pm 0.08^{\mathrm{a}}$ & $11.85 \pm 0.15^{\mathrm{b}}$ & $61 \pm 1^{c}$ \\
\hline 4 & 467 & $44.65 \pm 0.30^{\mathrm{a}}$ & $2.83 \pm 0.03^{\mathrm{bc}}$ & $7.49 \pm 0.09^{\mathrm{a}}$ & $12.13 \pm 0.15^{\mathrm{ab}}$ & $63 \pm 1^{\mathrm{ab}}$ \\
\hline 5 & 369 & $44.75 \pm 0.33^{\mathrm{a}}$ & $2.90 \pm 0.03^{\mathrm{a}}$ & $7.47 \pm 0.10^{\mathrm{a}}$ & $12.38 \pm 0.17^{\mathrm{a}}$ & $65 \pm 1^{\mathrm{a}}$ \\
\hline 6 & 382 & $44.94 \pm 0.36^{\mathrm{a}}$ & $2.87 \pm 0.04^{\mathrm{ab}}$ & $7.46 \pm 0.11^{\mathrm{a}}$ & $12.38 \pm 0.19^{\mathrm{a}}$ & $65 \pm 1^{\mathrm{a}}$ \\
\hline 7 & 197 & $43.63 \pm 0.42^{\mathrm{b}}$ & $2.83 \pm 0.05^{\mathrm{abcd}}$ & $7.45 \pm 0.13^{\mathrm{a}}$ & $12.13 \pm 0.22^{\mathrm{ab}}$ & $62 \pm 1^{\text {bcd }}$ \\
\hline Kind of rearing & & $* * *$ & $* * *$ & $* * *$ & Ns & $* * *$ \\
\hline group & 1652 & $40.65 \pm 0.22^{\mathrm{a}}$ & $2.73 \pm 0.02^{\mathrm{a}}$ & $7.16 \pm 0.06^{\mathrm{a}}$ & $12.06 \pm 0.11^{\mathrm{a}}$ & $57 \pm 1^{\mathrm{a}}$ \\
\hline individual & 739 & $47.67 \pm 0.35^{\mathrm{b}}$ & $2.92 \pm 0.04^{b}$ & $7.81 \pm 0.11^{\mathrm{b}}$ & $12.21 \pm 0.19^{\mathrm{a}}$ & $68 \pm 1^{b}$ \\
\hline Operator & & $* * *$ & $* * *$ & & $* * *$ & $* * *$ \\
\hline 1 & 1525 & $42.56 \pm 0.36^{\mathrm{a}}$ & $2.63 \pm 0.04^{\mathrm{a}}$ & - & $11.28 \pm 0.18^{\mathrm{a}}$ & $54 \pm 1^{\mathrm{a}}$ \\
\hline 2 & 866 & $45.76 \pm 0.61^{b}$ & $3.03 \pm 0.06^{\mathrm{b}}$ & - & $12.99 \pm 0.31^{\mathrm{b}}$ & $71 \pm 1^{b}$ \\
\hline
\end{tabular}

$*, * *, * * *$ Significant at level $0.05,0.01$ and 0.001 , respectively. Ns, Non-significant.

'Body weight at 6 months of age (BW6M); Fat-tail weight (EFTW); Needle measurement at GR site (NGR); Percentage of fat-tail (PEFTW); daily gain fat-tail (DGEFTW).

Male lambs had higher BW6M, EFTW, PEFTW and DGEFTW than female lambs but were lower for soft tissue depth. Subcutaneous fat was significantly higher in female lambs. Bedhiaf Romdhani and Djemali (2006) reported that Barbarine male lambs had lower fat depth than fe- males at 180 and 200 days. Sex differences were confounded by differences in age and weight (Kenney et al., 1995).

The single born lambs grew faster than twins $(\mathrm{P}<0.01)$. Kenney et al. (1995) show that twin lambs grew more slowly than single lambs. The 
fat-tail weight and percentage of fat-tailed weight of singles were higher than those of twins. The difference in the soft tissue depth among singles and twins was not significant. The age of dam was also found to have a significant effect $(\mathrm{P}<0.05)$ on BW6M, EFTW, PEFTW and DGEFTW. Lambs born from 2-yr-old ewes had significantly lower body weight compared to lambs born from the other groups (3 to 7-yr-old). EFTW and PEFTW traits lambs born from 4 to 6 -yr-old ewes were significantly higher than from the other age groups. BW6M, EFTW, NGR and DGEFTW in individual feeding lambs were significantly higher than in the group of feeding lambs but there was not significant difference in PEFTW between the two groups of lambs. The differences in fat-tail weight between the two types of rearing were due to the difference in body weight. Differences between rearing in live weight and fat reported by Kenney et al. (1995) and Bennett et al. (1991) may be associated with differences in nutrition between rearing types. The differences in body weight have been documented by a number of investigators (Rastogi, 2001; Gaafar et al., 2012).

The phenotypic trends body weight at 6 months of age, fat-tailed weight and soft tissue depth traits are shown in Table 3. The phenotypic change was significantly positive for the body weight at 6 months of age $(0.744 \mathrm{~kg} /$ year $)$ that was very higher than those of $<100 \mathrm{~g} /$ year which were reported by Bosso et al. (2007) in the post weaning of Djallonké sheep. This value is lower than the value obtained in the current study due to the difference body weight. The phenotypic trend which estimates for EFTW (-140 g/year) was significantly negative. The phenotypic trend of NGR was $-0.37 \mathrm{~mm} /$ year. The GR fat depth was the best predicator for the total subcutaneous fat (kenney et al. 1995). Eikje et al. (2008) reported that the phenotypic development for the fat grade was towards fatter carcasses with a regression of 0.061 in the Norwegian sheep. The increasing carcass weight and improving carcass composition should be considered together because an increase in the carcass weight coupled with a decline in composition, or improved carcass composition (greater \% lean and lower $\%$ fat) coupled with a lower carcass weight may not result in a net gain in carcass value. Bradford \& Spurlock (1972) concluded that weight per day of age is the single best selection criterion for increased lean meat production per animal.

Selecting for lower fat depth along with greater live weight is expected to result in more lean tissue and less fat tissue and thus, improved composition (Waldron et al., 1992). Therefore, the phenotypic selection would be effective for improvement of body composition by decreasing fattailed and subcutaneous fat. Thus, even with positive correlation between the body weight and fattail (Nejati-Javaremi et al. 2007), it is possible to increase the body weight and reduce the fat-tail size by the phenotypic selection.

\section{Table 3}

The phenotypic trends body weight at 6 months of age, fat-tailed weight and soft tissue depth traits in Lori-Bakhatiari sheep

\begin{tabular}{llcc}
\hline \hline Traits & Unit & phenotypic trend & $\mathrm{R}^{2}$ \\
\hline BW6M & kg/year & $0.774 \pm 0.23^{*}$ & 0.64 \\
EFTW & $\mathrm{kg} /$ year & $-0.140 \pm 0.02^{* *}$ & 0.90 \\
NGR & mm/year & $-0.37 \pm 0.14^{*}$ & 0.55 \\
\hline \hline
\end{tabular}

*, ** Significant at level 0.05 and 0.01 , respectively.

\section{CONCLUSION}

Consequently, according to the present study, considerable variation exists for body weight and fat traits, especially for subcutaneous fat and fattail. Environment factors were effective on body weight and fat traits. The phenotypic trend body weight at 6 months of age was positive. The phenotypic trends fat-tailed weight and soft tissue depth traits were negative. Improvement is possible for the body weight and body composition traits due to decreasing subcutaneous fat and fattail.

\section{REFERENCES}

[1] Bedhiaf Romdhani, S., Djemali, M. (2006): Estimation of sheep carcass traits by ultrasound technology. Livestock Science. 101: 294-299.

[2] Bennett, G. L., Kirton A. H., Johnson, D. L., Carter, A. H. (1991): Genetic and environmental effects on carcass characteristics of Southdown $\times$ Romney lambs. I. Growth rate, sex and rearing effects. J. Anim. Sci. 69, 1856-1863.

[3] Bosso, N. A., Cissé M. F., van der Waaij E. H., Fall, A., van Arendonk, J. A. M. (2007): Genetic and phenotypic parameters of body weight in West African Dwarf goat and Djalloonké sheep. Small Rumin. Res. 67, 271-278.

[4] Bradford, G. E., Spurlock, G. M. (1972): Selection for meat production in sheep - Results of a progeny test. $J$. Anim. Sci. 34, 737-745. 
[5] Cadavez, V. A. P. (2009): Prediction of lean meat proportion of lamb carcasses. Archiva Zootechnica. 12 (4), 4658.

[6] Eikje, L. S., Ådnøy, T., Klemetsdal, G. (2008): The Norwegian sheep breeding scheme: description, genetic and phenotypic change. Animal. 2 (2), 167-176.

[7] Farid, A., Izadifard, J., Edriss, M. A., Makarechian, M. (1983): Meat from culled old ewes of two fat-tailed Iranian breeds. II. Meat, subcutaneous fat and bone in the wholesale cuts. Iran. J. Agri. Res. 2, 93-114.

[8] Fogarty, N. M. (1995): Genetic parameters for liveweight, fat and muscle measurements, wool production and reproduction in sheep: a review. Anim. Breed. Abstr. 63, 101-143.

[9] Fogarty, N. M., Safari, E., Taylor, P. J., Murray, W. (2003): Genetic parameters for meat quality and carcass traits and their correlation with wool traits in Australian Merino sheep. Austr. J. Agri. Res. 54, 715-722.

[10] Gaafar, H. M. A., Hafsa F. H., Youssf, M., El-Din Shehab, T. (2012): Environmental factors affecting growth performance of growing lambs in Egypt. Archiva Zootechnica. 15 (1), 15-29.

[11] Hopkins, D. L. (1994): Predicting the weight of lean meat in lamb carcasses and suitability of this characteristic as a basis for valuing carcasses. Meat Sci. 38, 235-241.

[12] Jones, S. D. M., Robertson, W. M., Price, M. A., Coupland T. (1996): The prediction of saleable meat yield in lamb carcasses. Can. J. Anim. Sci. 76, 49-53.

[13] Kenney, P. A., Goddard, M. E., Thatcher, L. P. (1995): Genetic parameters for terminal sires estimated using data of progeny from Border Leicester $\times$ Merino ewes. Aust. $J$. Agric. Res. 46, 703-709.

[14] Kirton, A. H. (1989): Current methods of on-line carcass evaluation. J. Anim. Sci. 67, 2155-2163.

[15] Kirton, A. H., Johnson, D. L. (1979): Interrelationships between GR and other lamb carcass fatness measurements. Proc. N. Z. Soc. Anim. Prod. 39, 195-201.

[16] Kiyanzad, M. R. (2005): Comparison of carcass composition of Iranian fat-tailed sheep. Asian-Aust. J. Anim. Sci. 18 (9), 1348-1352.

[17] Kvame, T., Vangen, O. (2007): Selection for lean weight based on ultrasound and CT in a meat line of sheep. Livestock Science.106, 232-242.
[18] Larsgard, A. G., Kolstad, K. (2003): Selection for ultrasound muscle depth; direct and correlated response in a Norwegian experimental sheep flock. Small Rumin. Res. 48, 23-29.

[19] Nejati-Javaremi, A., Izadi, F., Rahimi, G., Moradi, M. (2007): Selection in fat-tailed sheep based on two traits of fat-tail and body weight versus single-trait body weight. Inter. J. Agri. Bio. 9, 645-648.

[20] Nsoso, S. J., Young, M. J., Beatson, P. R. (2004): Genetic and phenotypic parameters and responses in index component traits for breeds of sheep selected for lean tissue growth. Small. Rum. Res. 51, 201-208.

[21] Ramsey, C. B., Kirton, A. H., Hogg, B., Dobbie, J. L. (1991): Ultrasonic, needle and carcass measurements for predicting chemical composition of lamb carcasses. $J$. Anim. Sci. 69, 3655-3664.

[22] Rastogi, R. K. (2001): Production performance of Barbados black belly sheep in Tobago, West Indies. Small $R u-$ minant research, 41, 171-175.

[23] Safari, E., Fogarty, N. M., Gilmour, A. R. (2005): A review of genetic parameter estimates for wool, growth, meat and reproduction traits in sheep. Livest. Prod. Sci. 92, 271-289.

[24] SAS (2002): Release 9.00, SAS Institute Inc., Cary, North Carolia, USA.

[25] Simm, G. (1992): Selection for lean meat production in sheep. In Progress in sheep and goat research (ed. A. W. Speedy), pp. 193-215. CAB International, Wallingford.

[26] Simm, G., Lewis. R. M., Grundy, B., Dingwall, W. S. (2002): Responses to selection for lean growth in sheep. Anim. Sci. 74, 39-50.

[27] Solisramirez, J., Blair, H. T., Purchase, R. W. (1993): Direct and correlated responses to selection for high or low ultrasonic backfat depth in Southdown sheep. New Zealand J. Agric. Res. 36 (1), 133-141.

[28] Talebi, M. A., Vatankhah, M. (2011): Estimation of fattail weight by external fat-tail dimensions in LoriBakhtiari sheep. Journal of Agricultural Science and Technology, A: 1241-1244.

[29] Waldron, D. F., Clarke, J. N., Rae A. L. Kirton, A. H., Bennett, G. L. (1992): Genetic and phenotypic parameter estimates for selection to improve lamb carcass traits. $N$. Z. J. Agric. Res. 35, 287-298. 